\title{
FOREST HEALTH IMPACTS OF BARK BEETLES, DWARF MISTLETOE, AND BLISTER RUST IN A LAKE TAHOE BASIN MIXED CONIFER STAND
}

\author{
R.F. Walker ${ }^{1,2}$, R.M. Fecko ${ }^{1}$, W.B. Frederick ${ }^{1}$, D.W. Johnson ${ }^{1}$, and W.W. Miller ${ }^{1}$
}

\begin{abstract}
Interactions between forest health variables and mensurational characteristics in an uneven-aged eastern Sierra Nevada mixed conifer stand were examined. The stand was located in the Lake Tahoe Basin on a site featuring a coarsely textured granitic soil and numerous rock outcrops. Its composition was dominated by California white fir (Abies concolor var. lowiana [Gord.] Lemm.), with Jeffrey pine (Pinus jeffreyi Grev. \& Balf.) and sugar pine (Pinus lambertiana Dougl.) less prominent and incense-cedar (Libocedrus decurrens Torr.) and mountain alder (Alnus tenuifolia Nutt.) the most minor constituents. The majority of saplings and seedlings were white fir. The stand exhibited no evidence that its development had been influenced by fire and, overall, it consisted of numerous small trees accruing little radial growth. Nearly one-quarter of all standing stems pole size or larger were dead, with mortality concentrated in white fir. Forestfloor fuel accumulations were excessive, and coarse debris was especially prominent. A fir engraver beetle (Scolytus ventralis LeConte) epidemic in white fir contrasted against apparent endemic population levels of the Jeffrey pine (Dendroctonus jeffreyi Hopkins) and red turpentine (Dendroctonus valens LeConte) beetles in Jeffrey pine and of the mountain pine beetle (Dendroctonus ponderosae Hopkins) in sugar pine. The severity of fir engraver attack on white fir was weakly related to overall tree size and to the proportion of composition consisting of this host species, while in Jeffrey pine and sugar pine, bark beetle attacks were strongly correlated with the individual proportions of these 2 hosts. Across all species, basal area explained a substantial proportion of the variation in overall attack severity. We found light infestations of true fir dwarf mistletoe (Arceuthobium abietinum Engelm. ex Munz f. sp. concoloris) in white fir and western dwarf mistletoe (Arceuthobium campylopodum Engelm.) in Jeffrey pine, plus an early stage of infection by the white pine blister rust (Cronartium ribicola J.C. Fischer) in sugar pine. Collectively, this case study characterized and quantified many of the conditions, symptoms, and causative agents inherent in a decadent mixed conifer stand in the eastern Sierra Nevada.
\end{abstract}

Key words: forest health, bark beetle, fir engraver beetle, Jeffrey pine beetle, red turpentine beetle, mountain pine beetle, dwarf mistletoe, white pine blister rust, wildfire fuel, white fir, Jeffrey pine, sugar pine.

As is true for much of the western United States, forest health issues are paramount among the management concerns in Sierra Nevada forests (Covington et al. 1994, O'Laughlin and Cook 2003). Sierra Nevada mixed conifer (Tappeiner 1980), a common cover type at the mid-elevations of this mountain range, includes a variant on eastern slopes that features white fir, Jeffrey pine, and sugar pine. Currently, the most prevalent species in many of these stands is white fir, which is likely a substantial divergence from the historical norm (Helms 1995). Because of the ability of this species to persist in the shade of an overstory canopy (Laacke 1990), combined with selective harvesting of yellow and white pines during the Comstock mining era (Beesley 1996) and fire exclusion during the 20th century (Arno 2000, Taylor 2004), white fir now dominates many eastern Sierra Nevada forests. Furthermore, and in part due to the exces- sively high proportions of this species, these stands often feature large numbers of small stems, smaller tree spacings, relatively high canopy closure, and maladies that often accompany high densities, such as increased insect attack, tree mortality, and fuel loading (Helms and Tappeiner 1996), all of which are interrelated. In particular, the fir engraver beetle persists as a severe damaging agent in white fir (Laacke 1990, USDA Forest Service 2005), with the resulting mortality and fuel buildup predisposing many stands to catastrophic wildfire. Other concerns include the Jeffrey pine beetle as well as parasitic dwarf mistletoes in both white fir and Jeffrey pine (USDA Forest Service 2005), all having long been recognized as severely debilitating (Furniss and Carolin 1977, Jenkinson 1990, Laacke 1990, Scharpf and Hawksworth 1993). The exotic fungal disease white pine blister rust is the primary threat to sugar pine in the Sierra

${ }_{1}^{1}$ Department of Natural Resources and Environmental Science, University of Nevada, Reno, 1000 Valley Road, Reno, NV 89512.

22E-mail: walker@cabnr.unr.edu 
Nevada (Kinloch and Scheuner 1990, Bega and Scharpf 1993, Kinloch 2003). Although not currently as prevalent on the eastern slopes as on western slopes, its recent spread to east side stands (USDA Forest Service 2003) is particularly alarming in light of its lethality and the current scarcity of sugar pine on eastern slopes.

We examined forest health variables in a mixed conifer stand located in the Lake Tahoe Basin in order to identify possible links between mensurational characteristics and stand maladies. In addition to collecting routine mensurational measurements, we inventoried bark beetle activity and associated mortality, dwarf mistletoe infestation, white pine blister rust infection, stand regeneration, and downed and dead fuels. Regression analysis was used to identify tree and stand attributes that correlated with varying severity of bark beetle attack.

\section{Methods}

\section{Site Description}

An uneven-aged mixed conifer stand on the Nevada side of the Lake Tahoe Basin $\left(38^{\circ} 57^{\prime} 9^{\prime \prime} \mathrm{N}, 119^{\circ} 55^{\prime} 44^{\prime \prime} \mathrm{W}\right)$ was selected for the study. The stand was 6.5 ha in size and located at $2085 \mathrm{~m}$ on a western aspect with slopes of $10 \%-40 \%$. Average annual precipitation is 87 $\mathrm{cm}$, primarily snowfall (USDA Natural Resource Conservation Service 2006). The soil is of the Cagwin series (USDA Soil Conservation Service 1974), granitic in origin, coarse textured, and well drained. It features abundant rock outcrops that occupy approximately onequarter of the total land area.

\section{Vegetation Measurements}

The study was conducted at the end of the 2001 growing season. Sixteen permanent 0.04ha circular plots were established in a square pattern on the site for mensurational measurements of trees that were pole size and larger (i.e., $\geq 10.2 \mathrm{~cm} \mathrm{dbh}$; dbh of the bole was measured at $1.37 \mathrm{~m}$ above ground). These measurements consisted of total height, dbh, and live-crown length tallied by species, and this inventory included standing dead trees, which were identified as those lacking any live crown. Designation and coring (4.3-mm cores extracted $1.37 \mathrm{~m}$ above ground) of 1 site tree per plot that was randomly selected from among live trees of the dominant and codominant crown classes with good form permitted the determination of age, radial growth rate, and site quality, and also provided an indication of past wildfire incidence. We determined total age by counting late wood rings from pith to phloem and adding 10. Ten is an approximation of the years required for eastern Sierra Nevada conifers to reach a sufficient size to produce their 1st countable ring at breast height (Dunning 1942). Growth rate was determined by counting the rings in the outermost $2.54 \mathrm{~cm}$ of each core. Site quality was assessed using the site index (SI) curves of Schumacher (1926) for white fir, which utilize dominant crown-class trees only and a 50-year base age; the curves of Meyer (1938) for Jeffrey pine, which incorporate both dominant and codominant crown classes and a 100-year base age; and the curves of Dunning (1942) for Sierra Nevada mixed conifer, which also rely only on the dominant crown class but use a 300-year base age and assign a site class of A (highest overall) and then I through V (next highest to lowest) for a mixture of appropriate species, rather than assigning SI values for each species. For individual white fir and Jeffrey pine SIs, reference values were converted to metric units to achieve consistency with all other values reported here. Examination of each core for evidence of fire scars permitted the development of a wildfire history for the stand currently occupying the site.

Established with the same centers as those for the 0.04-ha plots, circular plots were also used to obtain counts of saplings $(>1.37 \mathrm{~m}$ tall to $\leq 10.1 \mathrm{~cm} \mathrm{dbh}$ ) and seedlings $(\leq 1.37 \mathrm{~m}$ tall $)$ by species. For this purpose, however, the plots for sapling counts were $54 \mathrm{~m}^{2}$, while the plots for the seedling counts were $40 \mathrm{~m}^{2}$.

\section{Forest Health Assessment}

To determine the severity of bark beetle attack, we used pitch-tube counts, which we recorded for all trees $\geq 10.2 \mathrm{~cm}$ dbh in the 0.04-ha plots. This was accomplished by visually dividing the bole surface into vertically oriented quadrants, counting the pitch tubes in each quadrant, and totaling the counts for the 4 quadrants of each tree. The entire bole length was included in these counts, with ocular aids used as needed. Identification of principal bark beetle species was accomplished by observation of adult and larval forms as well as pitch-tube and gallery characteristics as described by 
Furniss and Carolin (1977). Also, we assessed dwarf mistletoe infestation using the Hawksworth (1977) rating system with identification of specific parasite species following the descriptions of Scharpf and Hawksworth (1993). On sugar pine only, we tallied trees as having white pine blister rust infection if characteristic branch flagging or canker formation was present (Samman and Kitzmiller 1994).

\section{Fuels Inventory}

A downed- and dead-fuel inventory by timelag category (Pyne et al. 1996) was implemented using circular plots of $54 \mathrm{~m}^{2}$ for 1000-hour fuels, $4 \mathrm{~m}^{2}$ for 100-hour fuels, and $0.093 \mathrm{~m}^{2}$ for $1+10$ hour (combined) fuels, all centered in the 0.04ha plots. For 1000-hour fuels, log length and diameter at the midpoint were recorded by species as determined through bark characteristics (Little 1996) and were used to calculate volume according to the Huber formula (Avery and Burkhart 2002). To convert the volume in each plot to dry weight, $10 \log$ sections of a mixture of species were collected and their dimensions were measured. These sections were then dried to a constant weight, and their weights were recorded. For the 100-hour and $1+10$-hour fuels, all materials of appropriate size in their respective plots were dried to a constant weight, and the total weights for each plot were recorded.

\section{Statistical Analysis}

Prior to analysis, average dbh values by plot of trees $\geq 10.2 \mathrm{~cm}$ dbh were calculated using the quadratic mean formula (Curtis and Marshall 2000), and the basal area by plot was derived from these quadratic mean diameters (Davis et al. 2001). Tree heights and live-crown lengths were used to calculate live-crown proportions and percentages. Stem counts of trees $\geq 10.2 \mathrm{~cm}$ dbh, basal area, sapling and seedling counts, and dry weights of downed and dead fuels by plot were expanded to reflect equivalent 1.0-ha values. Subsequently, the standard error $\left(s_{\bar{x}}\right)$ and $95 \%$ confidence limits (CL) were calculated for all variables for the purpose of estimating how closely sample means reflected stand attributes.

Using dbh and height as approximations of base diameter and lateral length, we calculated the geometric formula for the lateral surface area of a right cone to provide an estimate of the bole surface area of trees $\geq 10.2 \mathrm{~cm} \mathrm{dbh}$, thus enabling us to express pitch tube counts by plot per unit bole surface area, in addition to total counts and counts per tree. We used a multiple regression analysis to examine relationships between the severity of bark beetle attack, as indicated by pitch tube counts per tree, the dependent variable, and several independent variables representing individual tree characteristics (i.e., species, height, dbh, and live-crown proportion). All species bearing pitch tubes were included. Quadratic terms for height, dbh, and live-crown proportion were also incorporated into the model, and only data for live trees $\geq 10.2 \mathrm{~cm}$ dbh were used for this analysis. As a component of the analysis, significant variables were retained and nonsignificant variables were removed using the $\mathrm{R}^{2}$ selection method, ultimately resulting in a bestfit model. The overall model and individual variables were considered significant when $P \leq$ 0.05 according to the $F$ test and $t$ test, respectively. Additionally, 18 simple linear regression models were developed to determine if significant correlations existed between selected independent and dependent variables. One subset of these models incorporated proportions of composition by species as independent variables with total and average pitch tube counts by tree species and pitch tube counts per unit bole surface area by tree species as dependent variables. The 2 nd subset incorporated basal area across all species as the independent variable, while for dependent variables, total and average pitch tube counts across all tree species and pitch tubes per unit bole surface area across all species were used. The 3rd subset featured basal area across all species as the independent variable while average pitch tubes by tree species and pitch tubes per unit bole surface area by tree species constituted the dependent variables. Again, only data for live trees $\geq 10.2$ $\mathrm{cm}$ dbh were included, and regression models were considered significant when $P \leq 0.05$ according to the $F$ test. All analyses were performed using SAS (SAS Institute, Inc., Cary, $\mathrm{NC}$ ) and a regression diagnostics SAS macro, REGDIAG (Fernandez 2002).

\section{RESUlTS}

\section{Stand Attributes}

More than one-half of the 508 trees $\geq 10.2$ $\mathrm{cm}$ dbh that were tallied in the stand were white fir, while approximately one-third were 
TABLE 1. Species composition of a mixed conifer stand in the Lake Tahoe Basin. Data were collected in 16 plots $(n=16)$ from trees $\geq 10.2 \mathrm{~cm}$ dbh.

\begin{tabular}{lccc}
\hline & $\begin{array}{c}\text { Mean } \\
\text { \% composition }\end{array}$ & $s_{\bar{x}}$ & 95\% CL $( \pm)$ \\
\hline White fir & 54.7 & 6.1 & 12.9 \\
Jeffrey pine & 34.3 & 6.5 & 13.9 \\
Sugar pine & 9.9 & 5.0 & 9.8 \\
Incense-cedar & 0.2 & 0.2 & 0.3 \\
Mountain alder & 0.9 & 0.9 & 2.0 \\
\hline
\end{tabular}

TABLE 2. Mensurational characteristics of a mixed conifer stand in the Lake Tahoe Basin. Data were collected in 16 plots $(n=16)$ from trees $\geq 10.2 \mathrm{~cm} \mathrm{dbh}$.

\begin{tabular}{lccc}
\hline & $\bar{x}$ & $s_{\bar{x}}$ & $95 \% \mathrm{CL}( \pm)$ \\
\hline Height $(\mathrm{m})$ & 11.6 & 0.6 & 1.3 \\
dbh $(\mathrm{cm})$ & 28.7 & 1.8 & 3.8 \\
Live crown $(\%)$ & 41 & 3 & 6 \\
Age $^{\text {a }}$ years $)$ & 106 & 7 & 14 \\
Growth rate $^{\mathrm{a}}\left(\mathrm{rings} \cdot \mathrm{cm}^{-1}\right)$ & 7.5 & 0.7 & 1.4 \\
Basal area $\left(\mathrm{m}^{2} \cdot \mathrm{ha}^{-1}\right)$ & 47.6 & 6.1 & 13.1 \\
Total trees $\left(\mathrm{stems} \cdot \mathrm{ha}^{-1}\right)$ & 785 & 120 & 255 \\
\hline
\end{tabular}

a Derived from dominant and codominant crown-class trees only.

TABLE 3. Species composition of saplings and seedlings in the understory of a mixed conifer stand in the Lake Tahoe Basin. Data were collected in 16 plots $(n=16)$.

\begin{tabular}{lccc}
\hline & $\begin{array}{c}\text { Mean } \\
\text { composition }\end{array}$ & $s_{\bar{x}}$ & $95 \%$ CL $( \pm)$ \\
\hline Saplings $^{\text {a }}$ & & & \\
White fir & 68.7 & 13.2 & 28.8 \\
Jeffrey pine & 30.8 & 13.3 & 29.0 \\
Sugar pine & 0 & 0 & 0 \\
Incense-cedar & 0.5 & 0.5 & 1.2 \\
Seedlings & & & \\
White fir & 86.5 & 6.3 & 13.9 \\
Jeffrey pine & 10.7 & 6.3 & 13.9 \\
Sugar pine & 1.2 & 0.8 & 1.8 \\
Incense-cedar & 1.6 & 1.1 & 2.4 \\
\hline
\end{tabular}

aStems $>1.37 \mathrm{~m}$ tall to $\leq 10.1 \mathrm{~cm} \mathrm{dbh}$

${ }^{b_{S}}$ Stems $\leq 1.37 \mathrm{~m}$ tall

Jeffrey pine (Table 1). Only about one-tenth of the stand composition was sugar pine. Minor constituents were incense-cedar and mountain alder.

Of the 16 dominant and codominant crownclass trees selected to determine site quality, 5 were white fir, 9 were Jeffrey pine, and 2 were sugar pine. Selection of white fir and Jeffrey pine site trees in numbers disproportionate to their overall prevalence was dictated by the need to choose trees of good form. Such trees were scarce for white fir. Nevertheless, this assessment indicated that our site was a $\mathrm{SI}_{50} 12$ site for white fir and a $\mathrm{SI}_{100} 21$ site for Jeffrey pine. Based on the Dunning approach for mixed conifer stands, it was site class IV.

Mean height, dbh, basal area, and stem counts of trees $\geq 10.2 \mathrm{~cm}$ dbh indicated that the overstory in this stand consisted of large numbers of small trees (Table 2). On average, less than one-half of tree height supported live crown. Mean age in the dominant and codominant crown classes was 98 years for white fir (range 56-132 years), 111 years for Jeffrey pine (range 83-179 years), and 88 years for sugar pine (range 78-98 years). Radial growth of 7.5 annual rings in the outermost centimeter equates to recent diameter growth of approximately $2.7 \mathrm{~mm} \cdot \mathrm{yr}^{-1}$. None of the increment cores exhibited evidence of fire scarring.

In the understory, more than two-thirds of saplings were white fir, while less than onethird were Jeffrey pine (Table 3). The remaining saplings were incense-cedar with no sugar pine saplings present. White fir comprised an even greater proportion of seedlings than saplings, and only approximately one-tenth of seedlings were Jeffrey pine. Sugar pine and incense-cedar seedlings were present in exceedingly small numbers. No saplings or seedlings of mountain alder were tallied in any plot. Overall, sapling counts equated to 394 per hectare, while those of seedlings equated to 2918 per hectare, but both were unevenly distributed as revealed by the absence of any saplings in 3 plots and any seedlings in 4 plots.

\section{Stand Health}

Overall, $23.6 \%$ of all standing trees $\geq 10.2$ $\mathrm{cm}$ dbh were dead at the time of the inventory, but mortality differed substantially by species (Table 4). Specifically, percent standing dead in white fir was more than 3 times that in Jeffrey pine, which in turn was 1.5 times that in sugar pine. No mortality had occurred in incense-cedar or mountain alder.

Counts of pitch tubes on trees $\geq 10.2 \mathrm{~cm}$ dbh also revealed substantial differences among species (Table 4). Overwhelmingly, bark beetle activity was concentrated in white fir, as nearly every tree inventoried exhibited pitch tube formation compared to approximately two-thirds of Jeffrey pine and even less of sugar pine. Furthermore, pitch tubes per white fir were approximately 28 times that in Jeffrey pine and 59 times that in sugar pine, while the count 
TABLE 4. Tree mortality and bark beetle infestation in a mixed conifer stand in the Lake Tahoe Basin. Data were collected in 16 plots $(n=16)$ from trees $\geq 10.2 \mathrm{~cm}$ dbh.

\begin{tabular}{|c|c|c|c|}
\hline & $\bar{x}$ & $s_{\bar{x}}$ & $95 \% \mathrm{CL}( \pm)$ \\
\hline \multicolumn{4}{|c|}{ Standing dead trees $(\%)$} \\
\hline White fir & 29.5 & 3.9 & 8.4 \\
\hline Jeffrey pine & 9.3 & 6.6 & 14.2 \\
\hline Sugar pine & 6.2 & 6.2 & 14.8 \\
\hline \multicolumn{4}{|c|}{ Trees with pitch tubes (\%) } \\
\hline White fir & 99.1 & 0.5 & 1.1 \\
\hline Jeffrey pine & 69.1 & 6.0 & 13.0 \\
\hline Sugar pine & 59.5 & 14.8 & 34.9 \\
\hline \multicolumn{4}{|c|}{ Pitch tube counts $\left(\right.$ number $\cdot$ tree $^{-1}$ ) } \\
\hline White fir & 94.1 & 9.8 & 21.1 \\
\hline Jeffrey pine & 3.4 & 1.0 & 2.1 \\
\hline Sugar pine & 1.6 & 0.5 & 1.1 \\
\hline \multicolumn{4}{|c|}{ Pitch tubes per unit bole surface area $\left(\right.$ number $\cdot \mathrm{m}^{-2}$ ) } \\
\hline White fir & 20.2 & 2.4 & 5.1 \\
\hline Jeffrey pine & 0.5 & 0.1 & 0.1 \\
\hline Sugar pine & 0.5 & 0.2 & 0.4 \\
\hline
\end{tabular}

TABLE 5. Coefficients and statistics of the best-fitting regression model for pitch tubes per white fir in a mixed conifer stand in the Lake Tahoe Basin $\left(F\right.$ test: $\left.\mathrm{R}^{2}=0.4221, P<0.0001\right)$. Data were collected in 16 plots $(n=16)$ from trees $\geq 10.2$ $\mathrm{cm}$ dbh.

\begin{tabular}{|c|c|c|c|c|}
\hline Model term & Parameter estimate & $s_{\bar{x}}$ & $P(t$ test $)$ & Standardized estimate \\
\hline Intercept & -119.6312 & 20.4606 & $<0.0001$ & 0 \\
\hline Height & 11.5652 & 5.2251 & 0.0281 & 0.8136 \\
\hline $\mathrm{dbh}$ & 9.8057 & 2.4092 & $<0.0001$ & 1.5262 \\
\hline Height $^{2}$ & -0.5747 & 0.1892 & 0.0027 & -1.0827 \\
\hline $\mathrm{dbh}^{2}$ & -0.0922 & 0.0395 & 0.0206 & -0.8342 \\
\hline
\end{tabular}

per unit bole surface area for the former was approximately 40 times those for both Jeffrey and sugar pine. Pitch tubes were absent on incense-cedar and mountain alder. Predominant in the attack on white fir was the fir engraver beetle. In the limited infestations of Jeffrey and sugar pine, both Jeffrey pine and red turpentine beetles were found in the Jeffrey pine while the mountain pine beetle was observed in sugar pine.

The initial multiple regression analysis revealed a highly significant $(P<0.0001)$ species effect on the severity of bark beetle attack, again reflecting that the preponderance of pitch tubes occurred on white fir. Consequently, subsequent analyses were performed on data for this species alone. Ultimately, these analyses revealed the significance of tree height, dbh, height ${ }^{2}$, and $\mathrm{dbh}^{2}$ in predicting pitch tube counts per tree; these variables were thus components of the best-fit model (Table 5), suggesting a positive but weak correlation between the severity of attack and overall tree size.
Nonsignificant variables were proportion of live crown and proportion of live crown squared.

Six of the 18 simple regression models that we developed were significant (Table 6). Three of the significant models, each revealing positive correlations, incorporated the individual proportions of white fir, Jeffrey pine, and sugar pine among trees $\geq 10.2 \mathrm{~cm}$ dbh as independent variables and the total numbers of pitch tubes on each of these species as the dependent variables. However, much more of the variation in total pitch tube counts was explained for the 2 pines than for the fir, and between the pines, more variation was explained in sugar pine than in Jeffrey pine. None of the models proved significant that incorporated the 3 independent variables indicated above and the average numbers of pitch tubes per tree in the 3 species as dependent variables. And for only sugar pine was a significant model revealed among the 3 with these independent variables and the counts per unit bole surface area as the dependent variables. Nevertheless, the lone significant 
TABLE 6. Simple linear regressions relating stand characteristics to bark beetle attack in a mixed conifer stand in the Lake Tahoe Basin. Data were collected in 16 plots $(n=16)$ from trees $\geq 10.2 \mathrm{~cm}$ dbh.

\begin{tabular}{|c|c|c|c|}
\hline Independent variable & Dependent variable & $\begin{array}{l}P \text {-value }(F \text { test }) \\
\quad \text { for model }\end{array}$ & $\mathrm{R}^{2}$ \\
\hline Proportion white fir & Total pitch tubes on white fir & 0.0200 & 0.3507 \\
\hline Proportion white fir & Average pitch tubes per white fir & 0.1821 & 0.1326 \\
\hline Proportion white fir & Pitch tubes per $\mathrm{m}^{2}$ of white fir ${ }^{\mathrm{a}}$ & 0.1663 & 0.1420 \\
\hline Proportion Jeffrey pine & Total pitch tubes on Jeffrey pine & 0.0001 & 0.7387 \\
\hline Proportion Jeffrey pine & Average pitch tubes per Jeffrey pine & 0.6277 & 0.0202 \\
\hline Proportion Jeffrey pine & Pitch tubes per $\mathrm{m}^{2}$ of Jeffrey pine & 0.2810 & 0.0960 \\
\hline Proportion sugar pine & Total pitch tubes on sugar pine & 0.0004 & 0.8937 \\
\hline Proportion sugar pine & Average pitch tubes per sugar pine & 0.2355 & 0.2246 \\
\hline Proportion sugar pine & Pitch tubes per $\mathrm{m}^{2}$ of sugar pine & 0.0484 & 0.4151 \\
\hline Basal area & Total pitch tubes across all species & 0.0003 & 0.6229 \\
\hline Basal area & Average pitch tubes across all species & 0.0381 & 0.2723 \\
\hline Basal area & Pitch tubes per $\mathrm{m}^{2}$ across all species ${ }^{\mathrm{a}}$ & 0.2973 & 0.0772 \\
\hline Basal area & Average pitch tubes per white fir & 0.9682 & 0.0001 \\
\hline Basal area & Pitch tubes per $\mathrm{m}^{2}$ of white fira & 0.2805 & 0.0889 \\
\hline Basal area & Average pitch tubes per Jeffrey pine & 0.3694 & 0.0676 \\
\hline Basal area & Pitch tubes per $\mathrm{m}^{2}$ of Jeffrey pine & 0.1990 & 0.1334 \\
\hline Basal area & Average pitch tubes per sugar pine & 0.6992 & 0.0267 \\
\hline Basal area & Pitch tubes per $\mathrm{m}^{2}$ of sugar pine & 0.5428 & 0.0648 \\
\hline
\end{tabular}

abole surface area

TABLE 7. Dry weight of downed and dead fuels on the forest floor of a mixed conifer stand in the Lake Tahoe Basin by timelag category. Data were collected in 16 plots $(n=$ 16).

\begin{tabular}{lrrr}
\hline & \multicolumn{1}{c}{ Mean } & & \\
& $\begin{array}{c}\text { dry weight } \\
\left(\mathrm{kg} \cdot \mathrm{ha}^{-1}\right)\end{array}$ & \multicolumn{1}{c}{$s_{\bar{x}}$} & \multicolumn{1}{c}{ CL $( \pm)$} \\
\hline $1+10$-hour $(\leq 2.5 \mathrm{~cm})$ & $54,551.7$ & $10,574.7$ & $22,534.6$ \\
100 -hour $(>2.5$ to $\leq 7.6 \mathrm{~cm})$ & 2674.4 & 926.5 & 1974.4 \\
1000 -hour $(>7.6 \mathrm{~cm})$ & $72,753.3$ & $35,159.3$ & $74,924.4$ \\
Total & $129,979.4$ & $36,274.0$ & $77,299.8$ \\
\hline
\end{tabular}

model here also indicated a positive correlation. The 2 remaining significant models, which also revealed positive correlations, each involved basal area as the independent variable. Dependent variables consisted of total and average pitch tube counts across all species, with basal area explaining a much greater proportion of the variation in the former than in the latter. All models that incorporated basal area as the independent variable and either average pitch tube counts by tree species or counts per unit bole surface area by species as dependent variables were not significant.

True fir dwarf mistletoe and western dwarf mistletoe were found in white fir and Jeffrey pine, respectively, of $\geq 10.2 \mathrm{~cm} \mathrm{dbh}$, but in both cases the Hawksworth rating was $<1$, indicating minor infestation levels. No mistletoe was ob- served in sugar pine, and dwarf mistletoe is not known to occur in incense-cedar or mountain alder. The flagging characteristic indicative of white pine blister rust was found on a total of 3 sugar pines, and 1 of these 3 also exhibited canker formation.

\section{Forest Floor Fuels}

The inventory of downed and dead fuels revealed that their distribution was not equitable across the various timelag categories (Table 7). Specifically, $56 \%$ of total dry weight consisted of 1000 -hour fuels, while $42 \%$ was combined $1+10$-hour fuels, and the 100-hour category constituted only $2 \%$. Furthermore, total fuel weight differed considerably across the site, ranging from $13,347.0$ to $553,181.7 \mathrm{~kg} \cdot \mathrm{ha}^{-1}$ depending on location. In the predominant 1000-hour timelag category, $96.3 \%$ of the dry weight was white fir debris, with the remainder solely Jeffrey pine. Bark was present on essentially all 1000-hour fuels, indicating that they represent relatively recent tree mortality.

\section{Discussion}

The composition of this stand was dominated by California white fir. This is especially undesirable for the site where this study was conducted because the annual precipitation falls below the $89 \mathrm{~cm}$ deemed minimal for this variety of the species (Laacke 1990). Nevertheless, 
despite its excessive mortality, the proportion of white fir in the overstory is likely to increase because the proportions of saplings and seedlings that were white fir were even greater than the proportion of white fir in the overstory. Conversely, the proportion of Jeffrey pine, which evidently preceded white fir on the site, as indicated by the difference between the 2 species in site tree age but which has probably been at a competitive disadvantage due partly to the absence of fire (Oliver et al. 1996, Tappeiner and McDonald 1996), is likely to diminish further because its proportion among saplings and seedlings was less, especially for the latter, than its proportion in the overstory. Furthermore, the stand exhibited mensurational features of overstocking, particularly minimal radial growth, despite a basal area that would not normally be deemed excessive even on sites of as low quality as that existing here (Schumacher 1926, Dunning and Reineke 1933, Laacke 1990). However, basal area is likely a misleading index of the density of this stand because of the prevalent rock outcrops that have precluded tree establishment on a substantial portion of the site, and because the stand consisted of exceptionally small trees in numbers that would be common on sites with much more uniform stocking (Schumacher 1926).

The most immediate threat to this stand was the mass fir engraver beetle attack on white fir, which apparently was largely responsible for the excessive mortality in this species. Comparatively, bark beetle activity in Jeffrey and sugar pine, along with tree mortality, was minor, a result in concert with findings of an early study of this bark beetle in Sierra Nevada mixed conifer (Ferrell 1971). Furthermore, the pitch tube counts used here to quantify the severity of attack may have understated the attack's intensity in white fir, because a level exists beyond which such attacks are sufficiently debilitating that trees cannot generate pitch in response to further wounding (Berryman and Ferrell 1988). Apparently, rapid expansion of the fir engraver population overwhelmed the defense mechanisms of the fir, as is typical in epidemic outbreaks (Christiansen et al. 1987, Berryman and Ferrell 1988, Edmonds et al. 2000). Among possible contributing factors in this occurrence was an average annual precipitation for the site that predisposed white fir to bark beetle attack (Edmonds et al. 2000), and this predisposition was exacerbated by a drought that began in
2000, extended through 2001, and featured precipitation approximating $83 \%$ and $59 \%$ of normal, respectively (USDA Natural Resource Conservation Service 2006). Inevitable impairment of water relations and overall tree vigor, and subsequent impacts on resinous defense mechanisms, probably increased host susceptibility to attack, with the aforementioned overstocking of the stand exacerbating this condition, although the effectiveness of resinbased defenses in fir are questionable (Ferrell 1983, Christiansen et al. 1987, Berryman and Ferrell 1988). Nevertheless, subnormal precipitation has been previously associated with fir engraver outbreaks (Ferrell and Hall 1975, DeMars et al. 1988, Ferrell et al. 1994), and high tree densities are frequently identified as predisposing forest stands of various compositions in the western United States to bark beetle attack by several species (Mitchell et al. 1983, Christiansen et al. 1987, Fiddler et al. 1989, Schmid and Mata 1992, 2005, Ferrell et al. 1994, Goyer et al. 1998).

The regression analyses revealed several mensurational features that likely contributed to the intensity of the bark beetle attack. Multiple regression indicated that in white fir, overall tree size was somewhat weakly but positively correlated with attack severity. This finding is in general agreement with that of Ferrell et al. (1994), who found that mortality resulting from the fir engraver beetle increased in higher crown classes, which in turn may reflect an earlier finding that larger white fir have lower percentages of bole surface area occupied by resin canals (Ferrell 1983). Relationships between tree size and attack severity were not revealed in Jeffrey or sugar pine, however, possibly because of the small numbers of pitch tubes they bore. Also, we did not find any indication that crown size in the fir was related to attack severity, a divergence from the Ferrell et al. (1994) finding that mortality from the fir engraver beetle was greater in trees with smaller crowns, which are associated with low vigor. This discrepancy may simply reflect that every white fir in the stand was infested to the maximum extent possible for the bole surface area, because it has been previously observed that when attack density thresholds are reached, surrounding trees not yet at this threshold are attacked instead (Ferrell 1971). The simple regressions revealed that total pitch tube counts, rather than average counts or, for the most 
part, counts per unit bole surface area by host species were positively correlated with the proportions of each tree species, but also that the correlations were much stronger in the 2 pines than in the fir. Collectively, these results suggest that in addition to the need of each beetle species for its specific host-the more prevalent the host the more numerous the colonizing beetles-the populations of the beetles attacking Jeffrey and sugar pine had not progressed to the epidemic stage found in the fir, and thus the Jeffrey pine and red turpentine beetles of the Jeffrey pine and the mountain pine beetles of the sugar pine were exhibiting opportunistic behavior in which they dispersed in limited numbers to available host trees as they encountered them rather than continuing to attack trees already colonized. Also, through simple regression we found a positive correlation between basal area and total pitch tube counts and, to a lesser extent, between basal area and average pitch tube counts. This suggests that the attack became more pervasive across all species as the crowding among trees increased, and, to a minor degree, the intensity of attack on individual trees increased as well. However, failure to find significant correlations between basal area and either average counts or counts per unit bole surface area by individual host species suggests that any influence of basal area on attack intensity was cumulative rather than concentrated in any 1 species.

Heavy dwarf mistletoe infestations are among damaging agents known to impart a stress that reduces overall tree vigor (Scharpf and Hawksworth 1993, Edmonds et al. 2000), and thus can predispose forest stands in the western United States to epidemic bark beetle outbreaks, including stands containing white fir (Laacke 1990). However, the mistletoe infestations that we encountered in the fir and Jeffrey pine were probably not major contributors to the distress of this stand, including the fir engraver epidemic, because both the true fir dwarf mistletoe of the fir and the western dwarf mistletoe of the Jeffrey pine were present at trace levels only, and none of the mortality in the stand could be attributed directly to these parasites. Likewise, the white pine blister rust in the sugar pine was limited to a few isolated trees. However, given the lethality, ease of spread, and limited genetic resis- tance within populations of this host (Kinloch and Scheuner 1990, Bega and Scharpf 1993, Samman and Kitzmiller 1994, Edmonds et al. 2000), coupled with the already low sugar pine representation on the site, white pine blister rust has the potential to effectively eliminate sugar pine from the stand. Compounding this threat was the scarcity of sugar pine seedlings in the understory and the complete absence of sugar pine saplings.

Downed- and dead-fuel loading on this site, although variable, was exceedingly high overall (Blonski and Schramel 1981, van Wagtendonk et al. 1998), with a large proportion resulting from accumulations in the combined $1+10$ hour timelag categories and even more accounted for by 1000-hour fuels. The former provides additional evidence that fire has not influenced stand development for an extended period, as fine fuels are typically the lst fuels consumed when burning occurs (Pyne et al. 1996). Conversely, the latter largely reflects recent and numerous deadfalls resulting from mortality in white fir, which will probably increase given the proportion of standing dead in this species. Forest floor debris serves vital ecosystem functions, with the fine component serving as a nutrient pool that is integral to nutrient cycling, as an insulating layer over mineral soil, and as a protective barrier against erosion and compaction (Fisher and Binkley 2000). Coarse materials also contribute to these functions but additionally provide wildlife habitat for varied fauna (Hagan and Grove 1999) and refuge during dry periods for microorganisms involved in nutrient cycling. However, the immoderate accumulations we observed, combined with the mortality in the overstory, portend stand-replacing wildfire, with the abundance of fine fuels predisposing ready ignition; the coarse debris contributing to the high temperatures and prolonged combustion that are especially destructive to forest soils; and the standing dead potentially serving as ignition points for lightning strikes as well as ladder fuels that facilitate the spread of ground fire into the upper canopy (Pyne et al. 1996).

In summary, this case study entailed examination of an array of forest health variables in an uneven-aged mixed conifer stand located in the Lake Tahoe Basin of the eastern Sierra Nevada. The overstory and regeneration were dominated by white fir on a site of marginal 
quality for this species, with Jeffrey pine and sugar pine assuming a lesser prominence, likely due in part to fire exclusion. Large numbers of small trees and minimal radial growth were among the mensurational features that suggested that the stand was overstocked. A fir engraver epidemic in white fir caused substantial mortality and subsequent elevated wildfire fuel loading, while bark beetle populations in the Jeffrey and sugar pines were apparently at or near endemic levels. Among other relationships, the extent of bark beetle attack by host species was positively correlated with their proportional representation among stand constituents, and, across species, with basal area. Other maladies detected were slight infestations of dwarf mistletoe in white fir and Jeffrey pine and an early stage of white pine blister rust infection in sugar pine.

\section{ACKNOWLEDGMENTS}

Funding for this research was provided by Nevada Agricultural Experiment Station Projects $523 \mathrm{M}, 523 \mathrm{P}$, and 5262 funded by the McIntire-Stennis Cooperative Forestry Research Program. This paper is NAES Publication No. 52077034. We thank J. Chacon, G. Fernandez, C. McCarthy, R. Ray, T. Rochelle, R. Salas, and J. Spurlock for their assistance.

\section{Literature Cited}

ARno, S.F. 2000. Fire in western forest ecosystems. Pages 97-120 in J.K. Brown and J.K. Smith, editors, Wildland fire in ecosystems. Volume 2, Effects of fire on flora. USDA Forest Service, General Technical Report RMRS-GTR-42, Ogden, UT.

Averr, T.E., AND H.E. Burkhart. 2002. Forest measurements. 5th edition. McGraw-Hill, New York.

BeEsLEY, D. 1996. Reconstructing the landscape: an environmental history, 1820-1960. Pages 3-24 in Status of the Sierra Nevada. Volume 2, Assessments and scientific basis for management options. University of California, Wildland Resources Center Report 37, Davis.

Bega, R.V., and R.F. Scharpf. 1993. Rusts. Pages 83-111 in R.F. Scharpf, technical coordinator, Diseases of Pacific Coast conifers. USDA Forest Service, Agriculture Handbook 521, Washington, DC.

Berryman, A.A., AND G.T. FerReLl. 1988. The fir engraver beetle in western states. Pages 555-577 in A.A. Berryman, editor, Dynamics of forest insect populations: patterns, causes, and implications. Plenum Press, New York.

Blonski, K.S., And J.L. Schramel. 1981. Photo series for quantifying natural resource residues: Southern Cascades and northern Sierra Nevada. USDA Forest
Service, General Technical Report PSW-56, Berkeley, CA.

Christiansen, E., R.H. Waring, and A.A. Berryman. 1987. Resistance of conifers to bark beetle attack: searching for general relationships. Forest Ecology and Management 22:89-106.

Covington, W.W., R.L. Everett, R. Steele, L.L. Irwin, T.A. DaER, AND A.N.D. AuClair. 1994. Historical and anticipated changes in forest ecosystems of the Inland West of the United States. Journal of Sustainable Forestry 2:13-63.

Curtis, R.O., AND D.D. Marshall. 2000. Why quadratic mean diameter? Western Journal of Applied Forestry 15:137-139.

Davis, L.C., K.N. Johnson, P.S. Bettinger, and T.E. HowARD. 2001. Forest management. 4th edition. McGraw-Hill, New York.

DeMars, C.J., G.T. Ferrell, and W.J. Otrosina. 1988. Host-insect/disease interactions in drought-stressed white fir stands at Lake Tahoe, California. Pages 135-146 in T.L. Payne and H. Saarenmaa, editors, Integrated control of scolytid bark beetles: proceedings of the IUFRO Working Party and XVII International Congress of Entomology Symposium, July 4, 1988, Vancouver, BC, Canada. College of Agriculture and Life Sciences, Virginia Polytechnic and State University, Blacksburg.

DunNING, D. 1942. A site classification for the mixed conifer selection forests of the Sierra Nevada. USDA Forest Service, California Forest and Range Experiment Station Research Note 28, Berkeley.

Dunning, D., And L.H. Reineke. 1933. Preliminary yield tables for second-growth stands in the California pine region. USDA Technical Bulletin 354, Washington, DC.

Edmonds, R.L., J.K. Agee, and R.I. Gara. 2000. Forest health and protection. McGraw-Hill, New York.

Fernandez, G.C.J. 2002. Data mining using SAS applications. Chapman and Hall/CRC Press, Boca Raton, FL.

Ferrell, G.T. 1971. Host selection by the fir engraver, Scolytus ventralis (Coleoptera: Scolytidae): preliminary field studies. Canadian Entomologist 103:17171725.

1983. Host resistance to the fir engraver, Scolytus ventralis (Coleoptera: Scolytidae): frequencies of attacks contacting cortical resin blisters and canals of Abies concolor. Canadian Entomologist 115:14211428.

Ferrell, G.T., AND R.C. HaLL. 1975. Weather and tree growth associated with white fir mortality caused by fir engraver and roundheaded fir borer. USDA Forest Service, Research Paper PSW-109, Berkeley, CA.

Ferrell, G.T., W.J. Otrosina, and C.J. DeMars. 1994. Predicting susceptibility of white fir during a droughtassociated outbreak of the fir engraver, Scolytus ventralis, in California. Canadian Journal of Forest Research 24:302-305.

Fiddler, G.O., T.A. Fiddler, D.R. Hart, and P.M. MCDONALD. 1989. Thinning decreases mortality and increases growth of ponderosa pine in northeastern California. USDA Forest Service, Research Paper PSW-194, Berkeley, CA.

Fisher, R.F., AND D. BINKLEY. 2000. Ecology and management of forest soils. 3rd edition. John Wiley \& Sons, Inc., New York. 
Furniss, R.L., and V.M. Carolin. 1977. Western forest insects. USDA Forest Service, Miscellaneous Publication 1339, Washington, DC.

Goyer, R.A., M.R. Wagner, and T.D. Schowalter. 1998. Current and proposed technologies for bark beetle management. Journal of Forestry 96:29-33.

Hagan, J.M., and S.L. Grove. 1999. Coarse woody debris. Journal of Forestry 97:6-11.

HawksworTh, F.G. 1977. The 6-class dwarf mistletoe rating system. USDA Forest Service, General Technical Report RM-48, Fort Collins, CO.

Helms, J.A. 1995. The California region. Pages 441-497 in J.W. Barrett, editor, Regional silviculture of the United States. 3rd edition. John Wiley \& Sons, Inc., New York.

Helms, J.A., AND J.C. TAPpeiner. 1996. Silviculture in the Sierra Nevada. Pages 439-476 in Status of the Sierra Nevada. Volume 2, Assessments and scientific basis for management options. University of California, Wildland Resources Center Report 37, Davis.

Jenkinson, J.L. 1990. Jeffrey pine. Pages 359-369 in R.M. Burns and B.H. Honkala, technical coordinators, Silvics of North America. Volume 1, Conifers. USDA Forest Service, Agriculture Handbook 654, Washington, DC.

KinLOCH, B.B., JR. 2003. White pine blister rust in North America: past and prognosis. Phytopathology 93: 1044-1047.

Kinloch, B.B., JR., AND W.H. SCheuner. 1990. Sugar pine. Pages 370-379 in R.M. Burns and B.H. Honkala, technical coordinators, Silvics of North America. Volume 1, Conifers. USDA Forest Service, Agriculture Handbook 654, Washington, DC.

LAacke, R.J. 1990. White fir. Pages 36-46 in R.M. Burns and B.H. Honkala, technical coordinators, Silvics of North America. Volume 1, Conifers. USDA Forest Service, Agriculture Handbook 654, Washington, DC.

LitTLE, E.L. 1996. National Audubon Society field guide to North American trees: western region. Alfred A. Knopf, New York.

MEYER, W.H. 1938. Yield of even-aged stands of ponderosa pine. USDA Technical Bulletin 630, Washington, DC.

Mitchell, R.G., R.H. Waring, and G.B. Pitman. 1983. Thinning lodgepole pine increases tree vigor and resistance to mountain pine beetle. Forest Science 29:204-211.

O'Laughlin, J., AND P.S. CoOK. 2003. Inventory-based forest health indicators: implications for National Forest management. Journal of Forestry 101:11-17.

Oliver, W.W., G.T. Ferrell, and J.C. Tappeiner. 1996. Density management of Sierra Nevada forests. Pages 491-500 in Status of the Sierra Nevada. Volume 3, Assessments, commissioned reports, and background information. University of California, Wildland Resources Center Report 37, Davis.

Pyne, S.J., P.L. Andrews, and R.D. Laven. 1996. Introduction to wildland fire. 2nd edition. John Wiley \& Sons, Inc., New York.
Samman, S., and J. Kitzmiller. 1994. How to identify blister rust infection and resistance in sugar pine. USDA Forest Service, Pacific Southwest Region/ Sugar Pine Regional Program, Camino, CA.

ScharpF, R.F., and F.G. Hawksworth. 1993. Mistletoes. Pages 112-135 in R.F. Scharph, technical coordinator, Diseases of Pacific Coast conifers. USDA Forest Service, Agriculture Handbook 521, Washington, DC.

SChMid, J.M., AND S.A. MatA. 1992. Stand density and mountain pine beetle-caused tree mortality in ponderosa pine stands. USDA Forest Service, Research Note RM-515, Fort Collins, CO.

2005. Mountain pine beetle-caused tree mortality in partially cut plots surrounded by unmanaged stands. USDA Forest Service, Research Paper RMRSRP-54, Fort Collins, CO.

Schumacher, F.X. 1926. Yield, stand, and volume tables for white fir in the California pine region. University of California, Agricultural Experiment Station Bulletin 407, Berkeley.

TAPPEINER, J.C. 1980. Sierra Nevada mixed conifer. Pages 118-119 in F.H. Eyre, editor, Forest cover types of the United States and Canada. Society of American Foresters, Washington, DC.

TAPPEINER, J.C., AND P.M. MCDONALD. 1996. Regeneration of Sierra Nevada forests. Pages 501-512 in Status of the Sierra Nevada. Volume 3, Assessments, commissioned reports, and background information. University of California, Wildland Resources Center Report 37, Davis.

TAYLOR, A.H. 2004. Identifying forest reference conditions on early cut-over lands, Lake Tahoe Basin, USA. Ecological Applications 14:1903-1920.

USDA Forest Service. 2003. Forest insect and disease conditions in the United States, 2002. USDA Forest Service, State and Private Forestry/Forest Health Protection, Washington, DC.

2005. Forest insect and disease conditions in the United States, 2004. USDA Forest Service, State and Private Forestry/Forest Health Protection, Washington, DC.

USDA Natural Resource Conservation Service. 2006. National Water and Climate Center: SNOTEL site information and reports for Heavenly Valley, California [online]. Available from: http://www.wcc.nrcs.usda .gov $/$ snotel $/$ snotel.pl ?sitenum $=518 \&$ state $=\mathrm{ca}$

USDA Soll Conservation SERvice. 1974. Soil survey of the Tahoe Basin area: California and Nevada. U.S. Government Printing Office, Washington, DC.

Van Wagtendonk, J.W., J.M. BENEDict, AND W.M. SydoRIAK. 1998. Fuel bed characteristics of Sierra Nevada conifers. Western Journal of Applied Forestry 13:7384.

Received 1 September 2006 Accepted 8 June 2007 